\title{
ANALISIS PERILAKU THREE-SIDED ARCH SEBAGAI ALTERNATIF DARI BOX CULVERT
}

\author{
Ida Bagus Prastha Bhisama', Made Sukrawa², Ida Ayu Made Budiwati ${ }^{3}$ \\ ${ }^{1,2,3}$ Program Studi Magister Teknik Sipil Universitas Udayana, \\ Email: prasthab@gmail.com
}

doi: https://doi.org/10.24843/SPEKTRAN.2021.v09.i01.p02

\begin{abstract}
ABSTRAK
Penelitian ini dilakukan untuk mengetahui perilaku dari struktur three-sided arch (TSA) yang merupakan salah satu alternatif dari struktur box culvert (BC). Perilaku kedua struktur dibandingkan melalui pemodelan elemen hingga pada program SAP2000. Pemodelan model validasi merupakan tahap awal dalam penelitian ini, yang dibuat berdasarkan pada hasil uji laboratorium oleh peneliti lain. Hasil pemodelan validasi menunjukkan bahwa pemodelan dengan elemen frame (MFR) dan shell (MSH) lebih mendekati hasil uji laboratorium, sedangkan elemen solid (MSO) jauh berbeda sehingga tidak digunakan dalam model aplikasi. Setelah metode pemodelan valid, selanjutnya dilakukan pemodelan aplikasi BC dan TSA yang memiliki panjang bentang bervariasi. Model aplikasi yang dibuat meliputi BC dan TSA dengan bentang $4 \mathrm{~m}$ (BC4 dan TSA4), $5 \mathrm{~m}$ (BC5 dan TSA5), $7 \mathrm{~m}$ (BC7 dan TSA7), $9 \mathrm{~m}$ (BC9 dan TSA9) dan $11 \mathrm{~m}$ (BC11 dan TSA11) dengan tebal pelat atas $400 \mathrm{~mm}$ pada model BC dan $300 \mathrm{~mm}$ pada TSA. Deformasi kedua model dianalisis secara non-linier menggunakan pembebanan bertahap, variasi modulus elastisitas (E) dan momen inersia penampang retak (Icr). Untuk mengetahui gaya-gaya dalam lainnya, kedua model dianalisis secara linier dengan beban lalu lintas sesuai SNI 1725:2016. Berdasarkan hasil analisis, perilaku TSA lebih baik dibandingkan BC, dilihat dari deformasi TSA yang mampu menyerupai atau bahkan lebih kecil dari BC meskipun dengan ketebalan pelat atas yang $25 \%$ lebih kecil. Pada model dengan variasi bentang, struktur mampu menahan kombinasi pembebanan lajur ' $D$ ' sampai dengan bentang $7 \mathrm{~m}$. Untuk model bentang 9 dan $11 \mathrm{~m}$, yaitu BC9, TSA9, BC11 dan TSA11 diperlukan penebalan pada pelat atas struktur.
\end{abstract}

Kata Kunci: box culvert, elemen frame, elemen shell, elemen solid, three-sided arc

\section{BEHAVIOR ANALYSIS OF THREE SIDED ARCH AS AN ALTERNATIVE OF BOX CULVERT}

\begin{abstract}
This research was conducted to determine the behavior of the three-sided arch (TSA) structure as an alternative to box culvert (BC). The behavior was compared through finite element modeling in the SAP2000 program. Initial stage of this research was validation model based on the results of laboratory tests by other researchers. The results show that frame (MFR) and shell (MSH) element models were able to mimic the test results, while solid element (MSO) was far different and not used. Application models in this research were BC and TSA with a span of $4 \mathrm{~m}$ (BC4 and TSA4), $5 \mathrm{~m}$ (BC5 and TSA5), $7 \mathrm{~m}$ (BC7 and TSA7), $9 \mathrm{~m}$ (BC9 and TSA9) and $11 \mathrm{~m}$ (BC11 and TSA11) with $400 \mathrm{~mm}$ top plate thickness on BC model and $300 \mathrm{~mm}$ on TSA. Deformation of both models were analyzed non-linearly using gradual loading, modulus of elasticity (E) variation and cracked section moment of inertia (Icr). To determine other behaviors, both models were analyzed linearly with traffic loads according to SNI 1725:2016. Based on the analysis results, the behavior of the TSA model was better than BC, it can be seen from the deformation of the TSA which was able to resemble or even smaller than BC although the thickness of the top plate was $25 \%$ smaller. In the model with span variation, the structure was able to withstand the load combination of lane 'D' up to a span of $7 \mathrm{~m}$. For the 9 and $11 \mathrm{~m}$ span models, namely BC9, TSA9, BC11 and TSA11, a thicker top plate was required.
\end{abstract}

Keywords: box culvert, frame element, shell element, solid element, three-sided arc 


\section{PENDAHULUAN}

Gorong-gorong/culvert merupakan struktur yang memungkinkan air mengalir di bawah jalan, rel kereta api, jalan setapak, atau halangan lainnya yang membentang dari satu sisi ke sisi lainnya. Terdapat beberapa tipe culvert, yaitu box culvert (BC), arch culvert (AC) dan three-sided arch (TSA). BC merupakan struktur yang tersusun atas pelat bawah, pelat atas, dan 2 dinding vertikal yang dibangun secara monolit dan membentuk sebuah struktur segi-empat tertutup (Polra et al., 2017). Sementara itu, TSA merupakan culvert dengan struktur pelat atas melengkung, namun dibangun tanpa pelat bawah dan dengan bentang yang lebih besar dibanding AC. Elemen horizontal (pelat atas) pada BC memikul beban dan menyalurkan beban tersebut ke elemen vertikal (dinding). Dinding dibebani secara aksial oleh pelat atas dan akan menyalurkan beban tersebut ke tanah. Kondisi pembebanan pada BC yang paling kritis adalah ketika dalam keadaan kosong dan terdapat beban hidup, beban mati serta tekanan tanah (Patil and Galatage, 2016). Sementara itu pada struktur TSA, beban yang diterima akan dialirkan ke sekitar permukaan melengkung, ke arah elemen horisontal, abutmen atau pondasi. Hubungan bentuk lengkung dan pola beban sangat menentukan kestabilitasan struktur (Limitstate: ring, 2011).

Di Indonesia, BC sudah banyak diterapkan pada proyek pelebaran jalan/drainase, seperti pada Proyek Pelebaran Jalan Imam Bonjol, Denpasar. BC lebih diminati karena pemasangannya yang mudah dan lebih cocok untuk proyek di Indonesia yang sebagian besar merupakan proyek pelebaran jalan dengan bentang yang relatif kecil. Sementara itu, untuk proyek pembangunan atau perbaikan jembatan, TSA menjadi populer khususnya di luar negeri (seperti di Amerika Serikat) karena singkatnya waktu konstruksi dan dampak minimnya dampak lingkungan yang disebabkan pada saluran air (Marshall et al., 2014).

Pada tahun 2018, Proyek Pelebaran Jalan Imam Bonjol Denpasar menggunakan BC bentang $5 \mathrm{~m}$ dengan ketebalan pelat atas dan bawah $400 \mathrm{~mm}$. Sementara itu, berdasarkan uji laboratorium yang dilakukan oleh Jensen (2012) yang bekerja sama dengan Foley Arch Company dari Amerika, diperoleh hasil bahwa struktur TSA dengan bentang $11 \mathrm{~m}$ hanya memerlukan pelat atas setebal $30 \mathrm{~cm}$ atau $10 \mathrm{~cm}$ lebih tipis dibandingkan BC pada proyek Imam Bonjol yang juga memiliki bentang lebih kecil yaitu $5 \mathrm{~m}$. Berdasarkan hal tersebut, terdapat potensi penghematan material sehingga perlu dilakukan penelitian terkait seberapa efektif TSA sebagai alternatif struktur BC.

Tahap awal penelitian dimulai dengan melakukan validasi model terhadap hasil uji laboratorium struktur BC dan TSA, kemudian dilanjutkan dengan pemodelan model aplikasi. Terdapat 5 model BC dan 5 TSA yang akan dimodel dalam penelitian ini. Model BC dan TSA dimodel dengan bentang $4 \mathrm{~m}$ (BC4 \& TSA4), $5 \mathrm{~m}$ (BC5 \& TSA5), 7 m (BC7 \& TSA7), 9 m (BC9 \& TSA9) dan 11 m (BC11 \& TSA11). Perilaku dari kedua struktur (deformasi, gaya-gaya dalam, luas tulangan dan tegangan) akan dianalisis dan dibandingkan dalam penelitian ini.

\section{THREE SIDED ARCH}

TSA menjadi salah satu alternatif struktur BC, baik dengan single-cell maupun multiple. Salah satu keuntungan utama dari penggunaan TSA untuk struktur yang berada di bawah tanah adalah mengurangi waktu fabrikasi dan instalasi, serta mengurangi jumlah pekerja yang dibutuhkan dibandingkan dengan pembuatan struktur secara konvensional (Beaver, 2016). Struktur TSA banyak digunakan pada jembatan bentang pendek, dikarenakan waktu konstruksi yang cepat. Dengan waktu konstruksi yang cepat, tentunya akan meminimalkan waktu penutupan jalan serta dampak lingkungan terhadap jalur air yang relatif kecil (AASHTO LRFD, 2013). Selain menjadi jalur air struktur TSA juga dapat diaplikasikan menjadi jalur penyebrangan bawah tanah pada bagian dalamnya.

Struktur TSA adalah sebuah struktur yang terdiri atas 2 dinding vertikal dan pelat atas melengkung yang membentang antara dua titik. Struktur utama pada pelat atas melengkung akan menerima gaya tekan disamping menerima lentur dan geser. Beban yang diterima akan diteruskan kepada tumpuan di kedua ujungnya. Ketika struktur tersebut menahan beban maka setiap bagian pelengkung menerima gaya tekan. Gaya tarik yang terjadi akan kecil sehingga momen lenturnya bernilai kecil.

Pada umumnya, struktur TSA dibuat dengan menggunakan material beton. Beton merupakan suatu material elastis ketika regangan terjadi dan menjadi tidak elastis ketika terjadi tegangan (Neville, 2011). Beton yang kuat akan gaya tekan, memiliki kelemahan dalam menahan gaya tarik. Hal ini terjadi karena munculnya retak yang menyebabkan penyaluran beban pada beton menjadi tidak merata. Kekuatan tarik dari beton adalah 0,10- 0,15 dari kuat tekan beton (Kosakoy et al, 2017). Beton dapat mengalami retak jika beban yang dipikulnya menimbulkan tegangan tarik yang melebihi kuat tariknya. Pada kondisi tersebut, inersia penampang beton akan tereduksi/lebih kecil daripada penampang utuh. Syarat inersia penampang retak maksimum untuk balok adalah 0,35 dari momen inersia gross (Ig) balok, sedangkan untuk kolom Icrnya adalah 0,7 dari momen inersia gross (Ig) kolom (BSN, 2013).

Terdapat 3 metode analisis dalam analisis struktur BC dan TSA, yaitu frame, shell dan solid element. Frame element dimodelkan sebagai garis lurus yang menghubungkan dua titik yang umumnya digunakan untuk memodelkan balok, kolom, dan rangka batang dalam bentuk struktur dua dan tiga dimensi. Elemen frame 
memilki 6 derajat kebebesan pada kedua joint yang terhubung dan sistem koordinat global X, Y, Z. Selain global, elemen frame juga memiliki sistem koordinat lokal yang dinotasikan sebagai 1,2,3 (Liu, 2003). Shell element adalah tiga atau empat nodal yang menggabungkan sifat membran yang memperhitungkan gaya-gaya sejajar bidang (in-plane forces) dan momen yang berputar pada sumbu tegak lurus bidang (drilling moment) dan elemen pelat yang memperhitungkan momen lentur dan gaya pada arah transversal yang bekerja tegak lurus bidang. Solid element adalah elemen dengan delapan node untuk memodel struktur dan benda padat dalam bentuk tiga dimensi. Solid element mempunyai enam penampang segi empat dengan titik (joint) pada setiap sudutnya.

Beberapa penelitian terkait pemodelan finite element BC dan TSA

\section{METODE}

Penelitian ini dimulai dengan pengumpulan data sekunder (geometri dan data material) untuk model validasi. Hasil dari model validasi dibandingkan dengan hasil uji laboratorium yang dilakukan oleh Jensen (2012). Setelah deformasi model validasi menyerupai hasil uji laboratorium, penelitian dilanjutkan dengan model aplikasi BC dan TSA dengan variasi bentang, yaitu bentang $4 \mathrm{~m}$ (BC4 dan TSA4), $5 \mathrm{~m}$ (BC5 dan TSA5), $7 \mathrm{~m}$ (BC7 dan TSA7), $9 \mathrm{~m}$ (BC9 dan TSA9) dan $11 \mathrm{~m}$ (BC11 dan TSA11) dengan tebal pelat atas $400 \mathrm{~mm}$ dan sudut kemiringan $\theta=27^{\circ}$ sesuai syarat pada (AASHTO LRFD, 2013). Lebar pelat atas pada seluruh model adalah $1200 \mathrm{~mm}$ dan tebal dinding $350 \mathrm{~mm}$. Kuat tekan beton yang digunakan adalah fc' $35 \mathrm{MPa}$ dan kuat tarik leleh baja tulangan fy $400 \mathrm{MPa}$.

Model aplikasi akan dimodel dengan elemen frame (FR) dan shell (SH) yang didefinisikan sebagai layered shell (CSI, 2016). Untuk mengetahui gaya-gaya dalam, luas tulangan dan tegangan, kedua struktur akan dibebani dengan beban lalu lintas sesuai yang disyaratkan pada (BSN, 2016). Uuntuk mengetahui perbandingan deformasi antara kedua model, digunakan variasi beban sesuai beban pada uji laboratorium, nilai modulus elastisitas (E) dan momen inersia penampang retak (Icr). Hasil perbandingan tersebut disajikan dalam bentuk grafik.

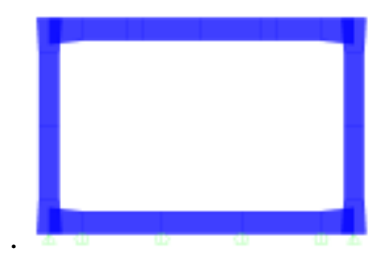

(a)

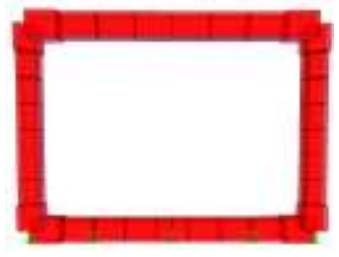

(b)

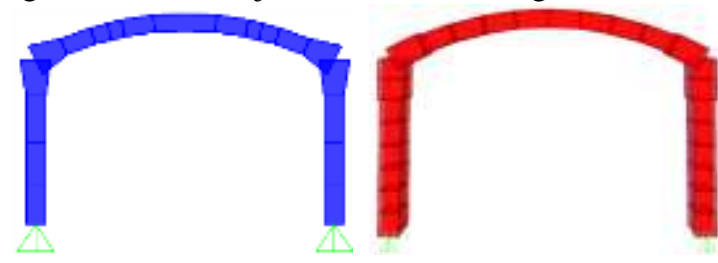

(c) (d)

Gambar 1. (a) BC5FR; (b) BC5SH; (c) TSA5FR dan (d) TSA5SH

Gambar 1 merupakan model aplikasi BC dan TSA bentang $5 \mathrm{~m}$ yang dimodel dengan elemen frame dan shell pada program SAP2000. Model aplikasi dengan variasi bentang akan dimodel dengan metode yang sama.

\section{HASIL DAN PEMBAHASAN}

Dalam penelitian ini, deformasi yang terjadi pada model validasi akan dibandingkan dengan deformasi hasil uji laboratorium. Setelah model tersebut valid, perilaku dari model aplikasi BC dibandingkan dengan TSA pada masing-masing variasi bentang.

\subsection{Model validasi}

Pada Model SAP2000, momen inersia (I) divariasikan dengan memperhitungkan penampang retak yang terjadi pada tepi beton akibat beban yang terjadi dan nilai modulus elastisitas (E) dengan menggunakan rasio nilai modulus elastisitas berdasarkan hasil uji laboratorium. 


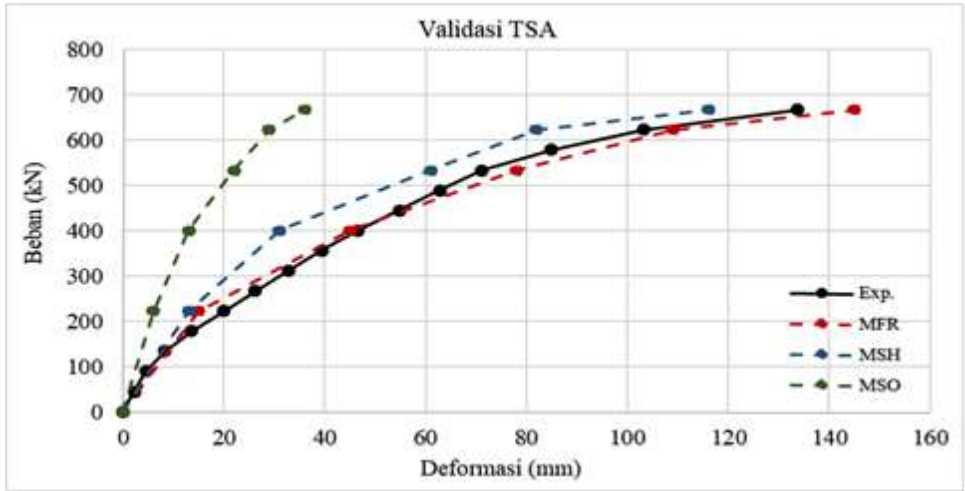

Gambar 2. Perbandingan Deformasi Hasil Uji laboratorim dengan Pemodelan

Dari Gambar 2, model validasi mampu menirukan deformasi model uji laboratorium pada kondisi linier dan non-linier, namun khusus pada elemen solid (SO) struktur masih jauh lebih kaku, sehingga hanya elemen frame dan shell yang digunakan pada model aplikasi.

\subsection{Model aplikasi BC4 dan TSA4}

Dari hasil perbandingan deformasi pada Gambar 3, model BC4 lebih kaku dari TSA4 karena tebal pelat pada BC4 adalah $400 \mathrm{~mm}$ sedangkan pada TSA4 dimodel dengan ketebalan pelat $300 \mathrm{~mm}$. Meskipun demikian perbedaanya tidak terlalu signifikan $(0.4-4.8 \mathrm{~mm})$, sehingga dapat dikatakan bahwa dengan tebal pelat atas yang $25 \%$ lebih kecil, perilaku TSA4 mampu menyerupai BC4.

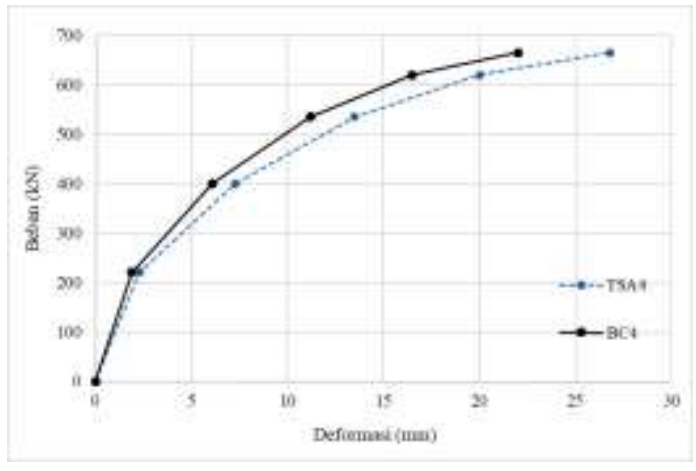

Gambar 3. Perbandingan Deformasi Model $4 \mathrm{~m}$

Besarnya gaya dalam yang terjadi pada BC4 dan TSA4 dengan kombinasi beban lajur "D" ditampilkan pada Gambar 4. Gaya aksial dan geser tepi yang terjadi pada kedua model hampir serupa. Momen yang terjadi pada TSA4 tengah bentang akibat beban lajur "D" 47\% lebih kecil dan pada tepi bentang 40\% lebih besar dibandingkan BC4. Berdasarkan hal tersebut, dapat dikatakan bahwa untuk bentang pendek (4 m), BC lebih direkomendasikan dibandingkan TSA.

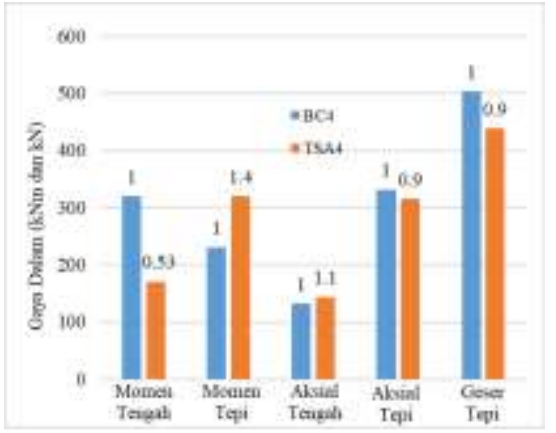

Gambar 4. Rasio Gaya Dalam Model $4 \mathrm{~m}$

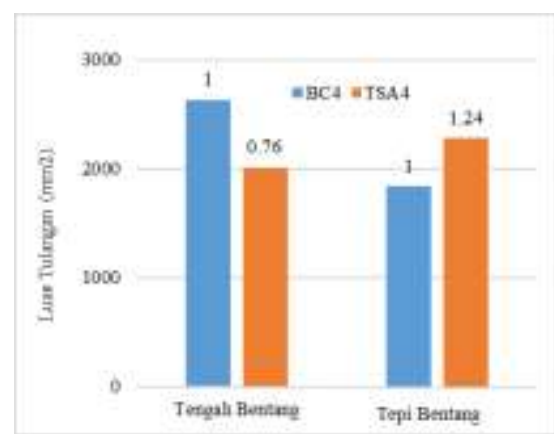

Gambar 5. Rasio Luas Tulangan Model $4 \mathrm{~m}$

Berdasarkan rasio perbandingan luas tulangan pada Gambar 5, TSA4 memiliki luas tulangan pada daerah lapangan yang 24\% lebih kecil dibandingkan BC4 dan 24\% lebih besar pada bagian tumpuan. Hasil tersebut menunjukkan bahwa struktur yang melengkung menghasilkan momen yang lebih kecil sehingga tulangan yang 
dibutuhkan pun semakin sedikit, namun hal ini hanya berlaku pada daerah tengah bentang dan pada tepi bentang model $4 \mathrm{~m}$, sehingga untuk bentang pendek (4 m) BC lebih direkomendasikan.

\subsection{Model aplikasi BC5 dan TSA5}

Berdasarkan Gambar 6, seperti pada perbandingan model bentang $4 \mathrm{~m}$ deformasi pada model BC5 lebih kecil dibanding TSA5. Model TSA5 tetap menggunakan tebal pelat atas yang $25 \%$ lebih besar dari BC, namun perilakunya mampu menyerupai BC yang ditunjukkan dengan deformasi yang terjadi antara kedua model sangat menyerupai saat menerima beban terkecil $(225 \mathrm{kN})$, dibandingkan pada model bentang $4 \mathrm{~m}$ dimana $\mathrm{BC}$ masih lebih kaku dari TSA pada beban yang sama.

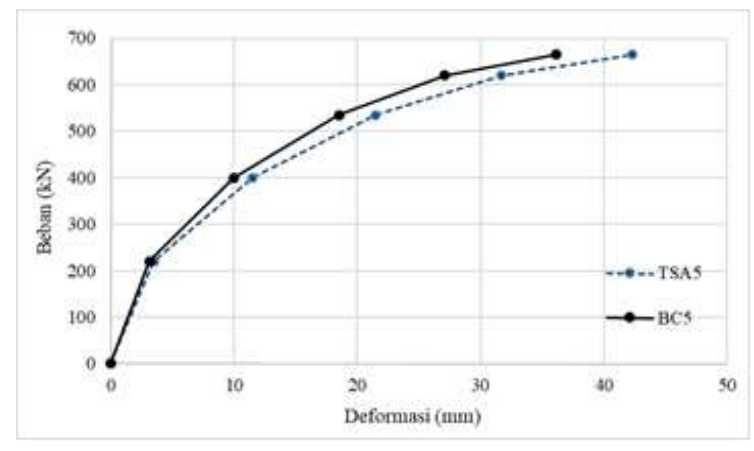

Gambar 6. Perbandingan Deformasi Model $5 \mathrm{~m}$

Berdasarkan Gambar 7, gaya aksial dan geser pada kedua model cenderung sama, sementara momen tengah pada TSA 45\% lebih kecil dibandingkan BC dan pada tepi 30\% lebih besar. Berdasarkan hal tersebut, TSA dengan tebal pelat atas $300 \mathrm{~mm}$ lebih kuat dibanding BC dengan tebal pelat atas $400 \mathrm{~mm}$ dengan bentang $5 \mathrm{~m}$.

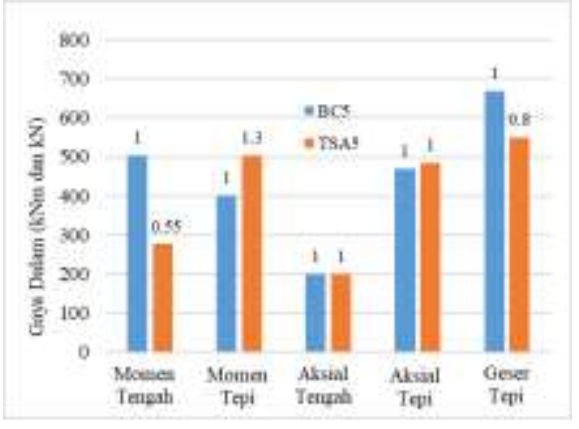

Gambar 7. Rasio Gaya Dalam Model 5 m

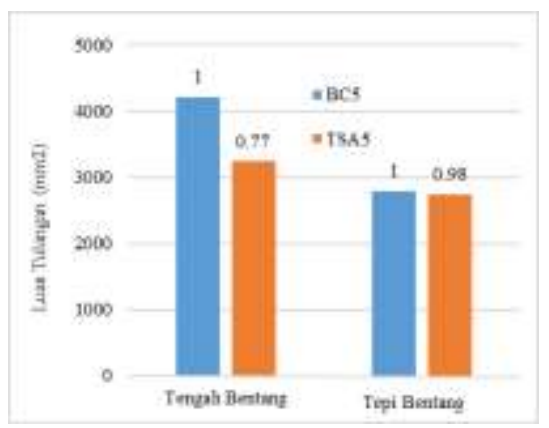

Gambar 8. Rasio Luas Tulangan Model $5 \mathrm{~m}$

Berdasarkan rasio perbandingan luas tulangan, pada daerah lapangan TSA5 memiliki luas tulangan yang $23 \%$ lebih kecil dibandingkan BC5, sementara pada bagian tumpuan relatif sama. Berdasarkan hasil tersebut, struktur yang melengkung menghasilkan momen yang lebih kecil sehingga tulangan yang dibutuhkan pun semakin sedikit, sehingga TSA5 lebih direkomendasikan dibandingkan BC5.

\subsection{Model aplikasi BC7 dan TSA7}

Berdasarkan perbandingan deformasi model bentang $7 \mathrm{~m}$ pada Gambar 9, TSA mulai terlihat lebih kaku dibandingkan BC. Hal ini menunjukkan bahwa untuk bentang $7 \mathrm{~m}$, perilaku dari struktur TSA lebih baik daripada BC meskipun dengan ketebalan pelat atas yang $25 \%$ lebih kecil. 


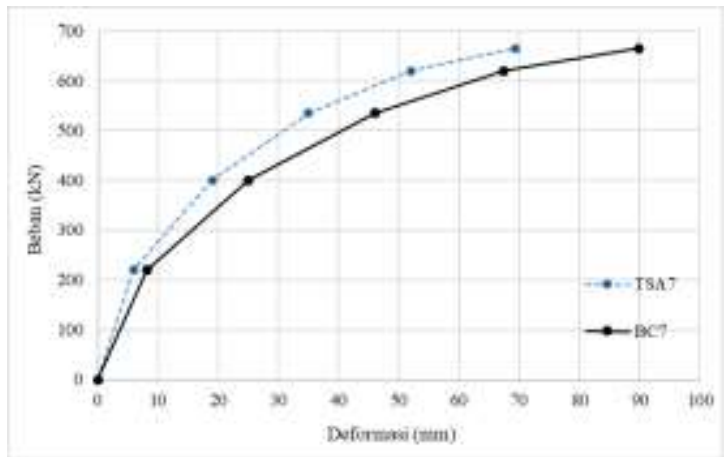

Gambar 9. Perbandingan Deformasi Model $7 \mathrm{~m}$

Berdasarkan Gambar 10, seperti halnya pada model 4 dan 5 meter, gaya aksial dan geser keda model cenderung sama. Sementara itu, momen tengah bentang pada TSA 56\% lebih kecil dibandingkan BC. Berdasarkan hal tersebut, dapat dikatakan bahwa untuk bentang panjang $(7 \mathrm{~m})$, TSA lebih direkomendasikan dibandingkan BC.

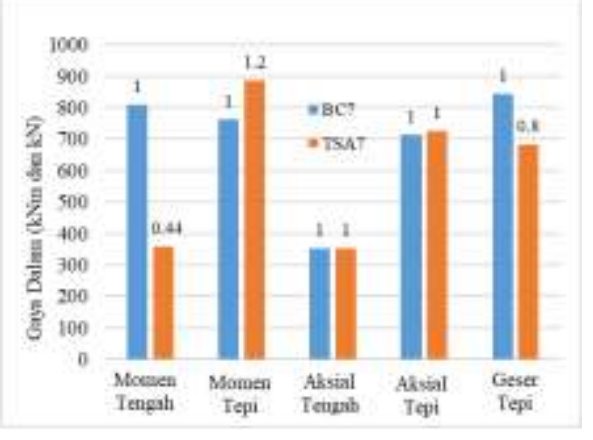

Gambar 10. Rasio Gaya Dalam Model 7 m

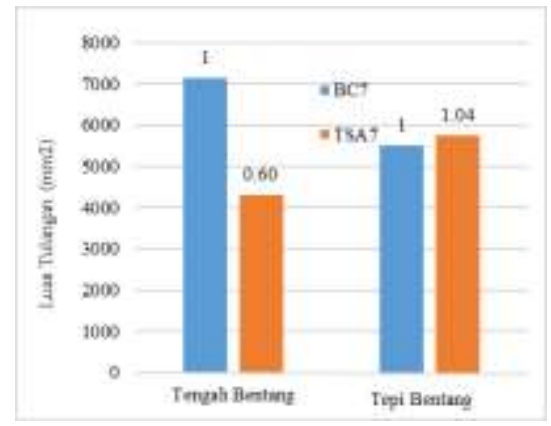

Gambar 11. Rasio Luas Tulangan Model $7 \mathrm{~m}$

Berdasarkan rasio perbandingan luas tulangan, pada daerah lapangan TSA7 memiliki luas tulangan yang $40 \%$ lebih kecil dibandingkan BC7, dan bagian tumpuan 4\% lebih besar. Berdasarkan hasil tersebut, dapat dikatakan bahwa struktur yang melengkung menghasilkan momen yang lebih kecil sehingga tulangan yang dibutuhkan pun semakin sedikit sehingga TSA7 lebih direkomendasikan dibandingkan BC7.

\subsection{Model aplikasi BC9 dan TSA9}

Berdasarkan hasil analisis dari model BC9 dan TSA9 dengan menggunakan tebal pelat atas $400 \mathrm{~mm}$ dan 300 $\mathrm{mm}$, pelat atas tersebut mengalami over stress dan sudah tidak mampu menahan beban lajur, sehingga tebal pelat atas BC ditebalkan menjadi $425 \mathrm{~mm}$ dan TSA menjadi $350 \mathrm{~mm}$. Berdasarkan grafik perbandingan deformasi pada Gambar 12, mulai terlihat perbedaan yang jelas antara deformasi kedua model, dimana deformasi pada model TSA lebih kecil dibandingkan BC. Hal ini menunjukkan bahwa untuk bentang $9 \mathrm{~m}$, perilaku dari struktur TSA lebih baik daripada BC meskipun dengan ketebalan pelat atas yang 18\% lebih kecil. Selain itu, berdasarkan perbandingan di atas serta perbandingan pada model $7 \mathrm{~m}$ terlihat bahwa seiring dengan bertambahnya bentang, perilaku TSA akan semakin lebih baik dibandingkan dengan BC.

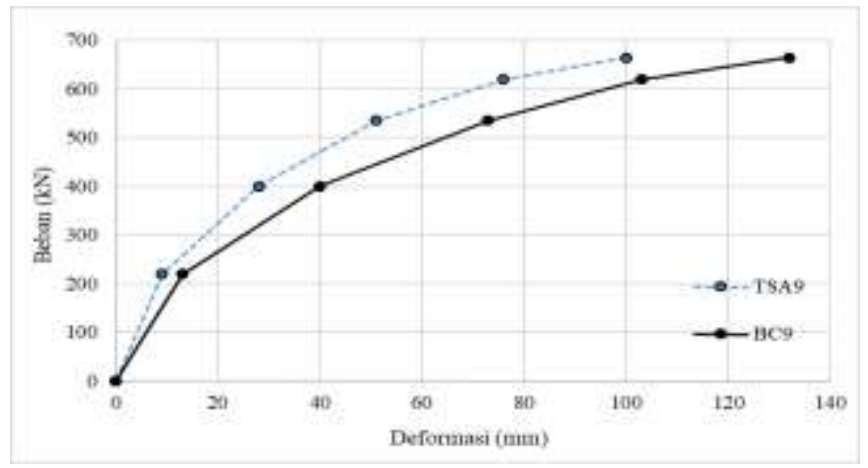

Gambar 12. Perbandingan Deformasi Model $9 \mathrm{~m}$ 
Dari Gambar 13, gaya geser dan aksial model 9 meter terlihat cenderng sama, kecuali pada geser tepi TSA9 yang 30\% lebih kecil dari BC9. Sementara itu, momen tengah pada TSA 50\% lebih kecil dibandingkan BC dan pada tumpuan relatif sama, sehingga dapat dikatakan bahwa untuk bentang panjang $(9 \mathrm{~m})$ TSA lebih direkomendasikan dibandingkan BC.

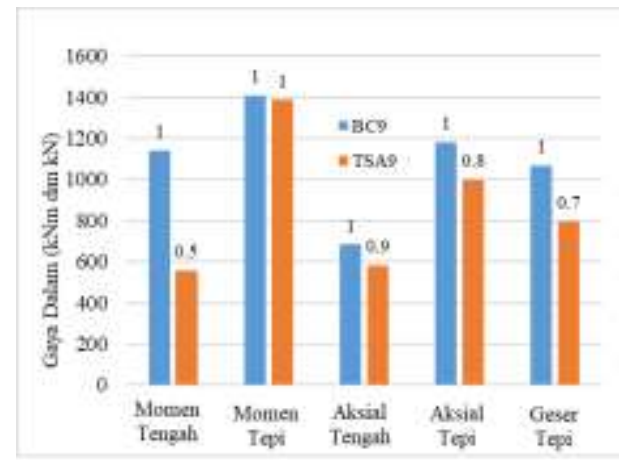

Gambar 13. Rasio Gaya Dalam Model $9 \mathrm{~m}$

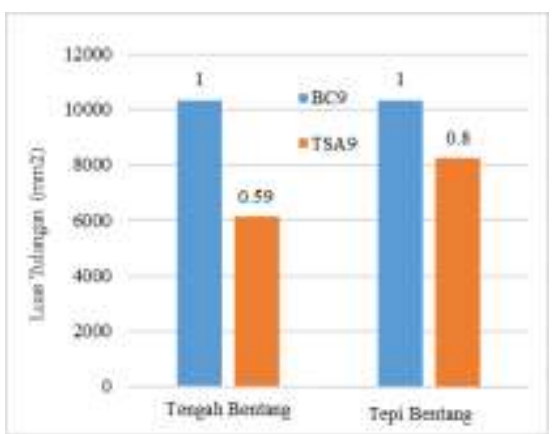

Gambar 14. Rasio Luas Tulangan Model $9 \mathrm{~m}$

Berdasarkan rasio perbandingan luas tulangan pada Gambar 14, pada daerah lapangan TSA9 memiliki luas tulangan yang $41 \%$ lebih kecil dan pada bagian tumpuan 20\% lebih kecil dibandingkan BC9. Berdasarkan hasil tersebut, dapat dikatakan bahwa struktur yang melengkung menghasilkan momen yang lebih kecil sehingga tulangan yang dibutuhkan pun semakin sedikit, sehingga TSA lebih direkomendasikan daripada BC untuk bentang $9 \mathrm{~m}$.

\subsection{Model Aplikasi BC11 dan TSA11}

Berdasarkan hasil analisis dari model BC11 dan TSA11 dengan menggunakan tebal pelat atas $400 \mathrm{~mm}$ dan $300 \mathrm{~mm}$, pelat atas tersebut mengalami over stress dan sudah tidak mampu menahan beban lajur, sehingga tebal pelat atas BC ditebalkan menjadi $450 \mathrm{~mm}$ dan TSA $350 \mathrm{~mm}$. Dari grafik perbandingan deformasi pada Gambar 15 , terlihat bahwa model TSA memiliki deformasi yang lebih kecil dibandingkan BC dan perbedaan deformasi antara kedua model terlihat semakin jelas dibandingkan dengan model bentang $9 \mathrm{~m}$. Hal ini menunjukkan bahwa untuk bentang $11 \mathrm{~m}$, perilaku dari struktur TSA lebih baik daripada BC meskipun dengan ketebalan pelat atas yang 22\% lebih kecil. Selain itu, berdasarkan perbandingan di atas serta perbandingan pada model 7 dan $9 \mathrm{~m}$ terlihat bahwa seiring dengan bertambahnya bentang, perilaku TSA akan semakin lebih baik dibandingkan dengan $\mathrm{BC}$.

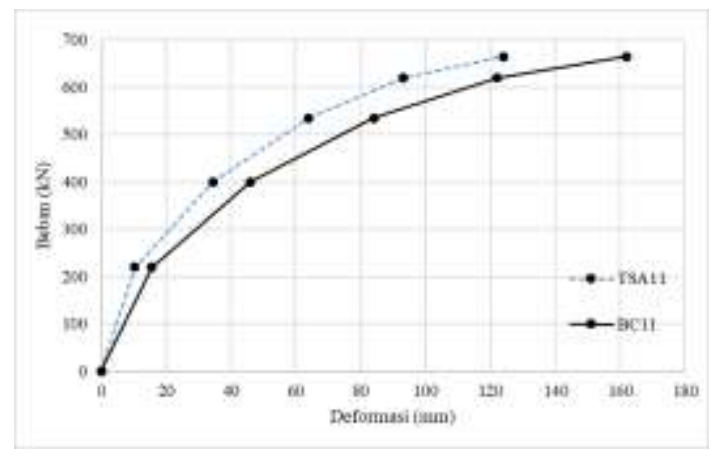

Gambar 15. Perbandingan Deformasi Model $11 \mathrm{~m}$

Dari Gambar 16, gaya aksial dan geser yang terjadi pada kedua model hampir serupa, sementara momen tengah yang terjadi pada TSA11 56\% lebih kecil dibandingkan BC. Berdasarkan hal tersebut, dapat dikatakan bahwa untuk bentang panjang $(11 \mathrm{~m})$, TSA lebih direkomendasikan dibandingkan BC. 


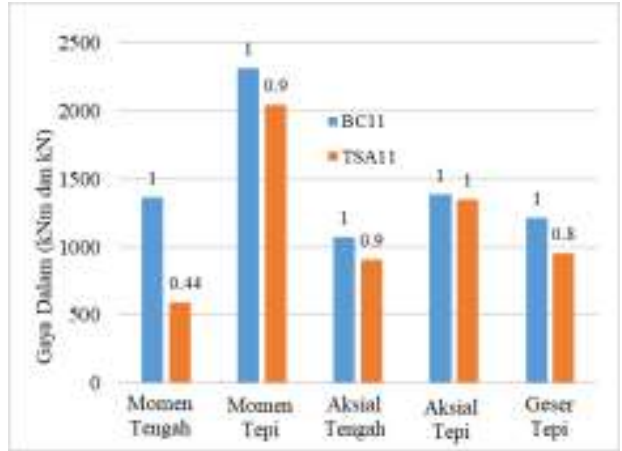

Gambar 16. Rasio Gaya Dalam Model $11 \mathrm{~m}$

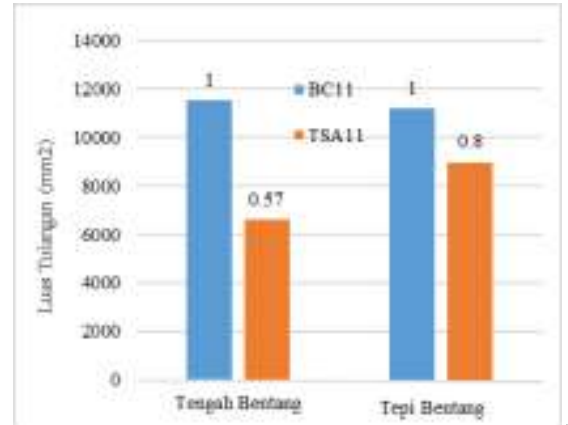

Gambar 1/. Kasio Luas I ulangan Model $11 \mathrm{~m}$

Berdasarkan rasio perbandingan luas tulangan, pada daerah lapangan TSA11 memiliki luas tulangan yang 43\% lebih kecil dibandingkan BC11 dan pada bagian tumpuan 20\% lebih kecil. Berdasarkan hasil tersebut, pada bentang panjang $(11 \mathrm{~m})$, struktur TSA lebih direkomendasikan dibandingkan dengan BC.

\section{KESIMPULAN}

Pada penelitian ini dilakukan dua jenis pemodelan, yaitu model validasi dan model aplikasi. Model validasi dilakukan pada three-sided arch TSA11 dengan referensi penelitian dari Jensen (2012) menggunakan element frame, shell, dan solid. Pada Model Aplikasi, dimodel BC dan TSA dengan dimensi yang bervariasi yaitu BC4, TSA4, BC5, TSA5, BC7, TSA7, BC9, TSA9, BC11 dan TSA11. Baik BC dan TSA pada model aplikasi dimodel dengan elemen frame dan shell.

Berdasarkan hasil dan pembahasan dari penelitian yang telah dilaksanakan maka dapat diambil kesimpulan sebagai berikut:

1. Pada Model Validasi dilakukan model non-linier menggunakan penampang retak dan modulus elastisitas (E) bervariasi sesuai dengan diagram tegangan - regangan beton, diperoleh hasil deformasi yang mendekati hasil deformasi pada TSA11 menurut uji lab oleh Jensen (2012). Dari 3 jenis elemen yang digunakan, elemen frame dan shell memberikan hasil yang mendekati hasil uji laboratorium, sedangkan elemen solid menghasilkan deformasi yang lebih kecil.

2. Berdasarkan hasil pemodelan aplikasi, diperlukan penebalan pelat atas pada model 9 dan $11 \mathrm{~m}$ akibat pelat dengan tebal $400 \mathrm{~mm}$ pada $\mathrm{BC}$ dan $300 \mathrm{~mm}$ pada TSA mengalami over stress, sehingga tebal pelat atas BC menjadi $450 \mathrm{~mm}$ dan TSA menjadi 325 dan $350 \mathrm{~mm}$ pada model tersebut.

3. Hasil perbandingan deformasi menunjukkan pada model bentang $4 \mathrm{~m}, \mathrm{BC}$ masih sedikit lebih kaku dibandingkan dengan TSA, sementara untuk bentang 5, 7, 9 dan $11 \mathrm{~m}$, deformasi TSA lebih kaku dibandingkan BC meskipun dengan tebal pelat atas yang 18-25\% lebih tipis dan akan semakin meningkat seiring dengan bertambahnya bentang. Dapat dikatakan bahwa BC hanya efektif untuk bentang pendek, sedangkan TSA akan semakin efisien untuk struktur dengan bentang panjang.

4. Dari hasil perbandingan gaya dalam dan tulangan, pada bagian tengah bentang momen TSA $45-56 \%$ lebih kecil dibandingkan BC dan kebutuhan tulangannya 20-41\% lebih kecil. Sementara pada bagian tepi, momen TSA lebih besar 20-30\% dan tulangannya 4-24\% lebih besar dibandingkan BC, yang hanya terjadi pada bentang 4, 5 dan $7 \mathrm{~m}$. Hal ini sesuai dengan teori bahwa pelat yang melengkung memiliki momen yang lebih kecil dibandingkan dengan pelat yang datar, sehingga tulangan yang dibutuhkan pun akan semakin sedikit.

\section{DAFTAR PUSTAKA}

AAHSTO. 2013. AASHTO LRFD Bridge Design Spesifications. American Association of State Highway and Transportation Officials. Washington, D.C., USA.

Badan Standardidasi Nasional. 2013. Persyaratan Beton Struktural untuk Bangunan Gedung (SNI 2847:2013). Badan Standardidasi Nasional. Jakarta

Badan Standarisasi Nasional. 2016. Pembebanan Jembatan (SNI 1725:2016).

Beaver, J. L., Gumpert, S. and Waltham, H. 2016. Introduction to Structural Design of Buried Bridges (Non-seismic). TRB Webinar

Computers and Structures. 2016. CSI Analysis Reference Manual. Computers and Structure Inc, Berkeley.

Jensen, T.J. 2012. Numerically Modeling Structural Behavior of Precast Three-Sided Arch Bridge for Analysis and Design. (Unpublished M.Sc. Thesis, Auburn University).

Kosakoy, M.N.M., Wallah, S.E., dan Pandaleke, R. 2017. Perbandingan Nilai Kuat Tarik Langsung dan Tidak Langsung pada Beton yang Menggunakan Fly Ash. Jurnal Sipil Statik. Vol. 5, pp. 383 to 392.

LimitState Ltd. 2011. Technical Note - The Influence of Arch Shape on Masonry Arch Bridge Capacity. Sheffield: LimitState Ltd. 
Liu, Y. 2003. Lecture Notes: Introduction to the Finite Element Method. Cincinnati, Ohio.

Marshall. J., Anderson, J.B., Meadows, R.L., Jentsen, T.J. 2014. Full-scale Testing of Three-Sided Precast Concrete Arch Sections. Journal of Bridge Engineering. Vol. 19, (12).

Neville, A.M. 2011. Properties of Concrete. 5th Edition. Pearson Education Limited, England.

Patil, A.D. and Galatage, A.A. 2016. Analysis of Box Culvert under Cushion Loading. International Advanced Research Journal in Science, Engineering and Technology. Vol. 3 (6), pp. 163-166.

Polra, A.R., Chandresha, S.P. and Parikh, K.B. 2017. A Review Paper on Analysis and Cost-Comparison of Box Culvert for Different Aspect Ratio of Cell. International Journal of Engineering Trends and Technology (IJETT). Vol. 44, No. 2. 